\title{
Microbial activity of soil cultivated with corn in association with weeds under different fertility management systems
}

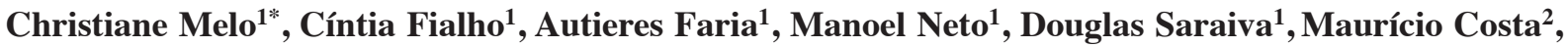 \\ Lino Ferreira ${ }^{1}$, and Francisco Affonso Ferreira ${ }^{1}$
}

Interactions between weeds and soil microorganisms can give them a competitive advantage over crops. This study assessed the biomass and microbial activity of soil cultivated with weeds and corn (Zea mays L.) in monoculture and in competition under different fertility management systems. The experiment considered four soil fertility management systems (calcium and magnesium silicate + fertilization; limestone + fertilization; no correction source + fertilization; no correction source + no fertilization) and 12 crops (five competition arrangements between corn and weeds Urochloa brizantha (Hochst. ex A. Rich.) R.D. Webster, Ipomoea grandifolia (Dammer) O’Donell, Conyza canadensis (L.) Cronquist, Hyptis suaveolens (L.) Poit., and Bidens pilosa L. plus the six species in monoculture and bare soil. After $60 \mathrm{~d}$ coexisting in a greenhouse, soil samples were collected to determine microbial biomass, respiration rate, and metabolic quotient. Soils cultivated with B. pilosa and Z. mays $+U$. brizantha showed higher microbial biomass. Cultivation of B. pilosa and Z. mays $+H$. suaveolens provided greater energy efficiency to maintain microbial cells. Biomass and microbial activity were altered by plant species, coexistence, and soil fertility management. Calcium and magnesium silicate, as well as limestone similarly influenced biomass and respiration rate of soil cultivated with most species. For some crops, the Si source was better than limestone to promote lower specific activity of the edaphic microbiota. The change in the microbial activity of soil can be a strategy used by the species to minimize the effects of competition.

Key words: Calcium and magnesium silicate, soil microorganism/weed interaction, interference, limestone, microbial biomass, soil metabolic quotient, Zea mays.

\section{INTRODUCTION}

Soil microorganisms are involved in various processes of major agronomic interest, such as organic matter decomposition, biological $\mathrm{N}$ fixation, antagonistic action to pathogens, production of growth-promoting substances, and nutrient cycling. The rhizosphere is the region that is directly influenced by the roots, and this is where most of the interactions between microorganisms and plants occur (Hirsch et al., 2003). It is characterized by a greater proliferation of microbial populations due to the transfer of $\mathrm{C}$ from the root to the soil as exudates, secretions, lysate, and mucilage (Baudoin et al., 2003). This deposition of substances plays an important role in regulating symbiotic associations between plants and soil microorganisms (Hirsch et al., 2003; Bais et al., 2004).

\footnotetext{
${ }^{1}$ Universidade Federal de Viçosa UFV, Centro de Ciências Agrárias, Av. PH Rolfs, s/n, Campus Universitário, Viçosa-MG, CEP 36570900, Brasil. "Corresponding author (christiane.melo@ufv.br).

${ }^{2}$ Universidade Federal de Viçosa UFV, Centro de Ciências Biológicas e da Saúde, Viçosa-MG, Brasil.

Received: 4 December 2013.

Accepted: 21 August 2014.
}

doi: $10.4067 /$ S0718-58392014000400015
Soil microbial communities are influenced by many factors, including cover crops and soil management (Ferreira et al., 2010), development stage of plants and cultivars (Ferreira et al., 2008), fertilizer type (Carrera et al., 2007), and pesticide application (Ferreira et al., 2009). Studies about the interactions between plants and soil microorganisms are important to understand a variety of processes, such as nutrient cycling, ecosystem functioning, and C sequestration (Singh et al., 2004). However, there is little information about such interactions involving different species, especially weeds in various soil conditions.

The competitive ability of a species is related to the efficient use of resources from the environment and can also be related to the interactions established between these plants and soil microbes. Research on the association between soil microorganisms and weeds is still incipient and can help to understand the influence of these interactions in competitive relationships between plants. According to Reinhart and Callaway (2006), the competitive success of weeds over the crop can partly result from the interaction of the first with different groups of soil microorganisms that can facilitate invasion or inhibit plant establishment in certain areas.

Therefore, we considered the following hypotheses in 
the present study: (i) competitive relationships between weeds and crops involve changing the composition and activity of soil microbes; and (ii) this change can vary depending on soil fertility management. To investigate these hypotheses, the aim of this study was to evaluate the microbial biomass and activity of soil cultivated with weeds and monoculture corn (Zea mays L.) competing under different fertility management systems.

\section{MATERIALS AND METHODS}

Soil samples used for the present study were from a previous crop established in Cajuri (20 46'19" S, 4246’20" W; 678.74 m a.s.1.), Minas Gerais, Brazil. Cultivation was carried out after superficial application of limestone (5.68 $\mathrm{t} \mathrm{ha}^{-1}$ dolomitic limestone: $33.3 \%$ $\mathrm{CaO}$ and $22.4 \% \mathrm{MgO}$ with $104.8 \% \mathrm{CaCO}_{3}$ equivalent) or calcium and magnesium silicate (7.01 t ha-1 AgroSilício: $34.9 \% \mathrm{CaO}, 9.9 \% \mathrm{MgO}$ and $22.4 \% \quad \mathrm{SiO}_{2}$ with $85 \%$ $\mathrm{CaCO}_{3}$ equivalent). In 2008, 2009, and 2010, corn (Zea mays 'hybrid DKB 390') and signal grass (Urochloa brizantha [Hochst. ex A. Rich.] R.D. Webster 'Marandú') were cultivated by intercropping in a no-till system. Crops were fertilized with $500 \mathrm{~kg} \mathrm{ha}^{-1}$ NPK 8-24-12 formulation $+0.4 \% \mathrm{Zn}$ and $0.2 \% \mathrm{~B}$ and $500 \mathrm{~kg} \mathrm{ha}^{-1} 30-0-10$ in each crop year. After harvesting the corn, the area was grazed by cattle until $20 \mathrm{~d}$ before the next crop.

Fertilization and acidity correction were applied differently. The area was divided into four plots: acidity correction with calcium and magnesium silicate + fertilization (SF), acidity correction with limestone + fertilization (LF), no acidity correction + with fertilization $(\mathrm{NF})$, and no acidity correction + no fertilization $(\mathrm{NN})$. In April 2011, samples at a depth of 0-10 cm of each plot were collected, chemically characterized, and used in the experiment (Table 1).

The experiment was set up and conducted in a greenhouse in a factorial $4 \times 12$ scheme with a randomized block design with three replicates. Factors consisted of four soil fertility management systems and 12 crops, which resulted in five competition arrangements between corn and weeds plus the six species in monoculture and bare soil.

Five species of weeds were evaluated (U. brizantha, Ipomoea grandifolia (Dammer) O'Donell, Hyptis suaveolens (L.) Poit., Conyza canadensis (L.) Cronquist, and Bidens pilosa L.); they were chosen because of their common occurrence in the experimental area where soil samples were collected.

Prior to filling the pots, all soil samples were fertilized with ammonium sulfate $\left(0.20 \mathrm{~g} \mathrm{~N} \mathrm{dm}^{-3}\right)$, single superphosphate $\left(0.20 \mathrm{~g}_{2} \mathrm{O}_{5} \mathrm{dm}^{-3}\right)$, and potassium chloride $\left(0.18 \mathrm{~g} \mathrm{~K}_{2} \mathrm{O} \mathrm{\textrm {dm } ^ { - 3 }}\right)$, and distinct characteristics were maintained from the application of correction sources of acidity and residual fertilizer in the field.

Corn seeds ('hybrid 390 VT Pro') were then distributed simultaneously to the weeds in pots containing $5.5 \mathrm{~kg}$ substrate. After thinning, one corn plant in the center over four weeds of the same species remained in each container, thus forming five competition arrangements. The experimental unit consisted of a pot containing a corn plant or a weed alone or in competition. Plants were irrigated as needed to maintain soil moisture near field capacity.

After emergence of all the species, $10 \mathrm{~d}$ after sowing, thinning was begun and the corn coexisted with the weeds for over $55 \mathrm{~d}$. At this time, corn plants had 6 to 8 expanded leaves and weeds were in the vegetative stage, with the exception of $B$. pilosa and $H$. suaveolens which were in the flowering stage.

After removing the root system and homogenizing the soil of each experimental unit, samples were collected, placed in plastic bags that were tied loosely, and kept under refrigeration to determine the moisture equivalent and conduct microbiological testing in the laboratory. Microbial biomass $\mathrm{C}$, respiration rate, and metabolic quotient of the soil were estimated.

To assess the respiration rate, we used the respirometric method of evolution $\mathrm{C}-\mathrm{CO}_{2}$. Soil samples and duplicated (100 $\mathrm{g}$ of sifted soil with humidity equal to $60 \%$ field capacity) were incubated for $15 \mathrm{~d}$ in tightly closed flasks. The $\mathrm{C}-\mathrm{CO}_{2}$ released from the soil was transported by continuous flow of $\mathrm{CO}_{2}$-free air to another flask containing $70 \mathrm{~mL} \mathrm{NaOH}$ solution $\left(0.5 \mathrm{~mol} \mathrm{~L}^{-1}\right)$. The $\mathrm{C}-\mathrm{CO}_{2}$ was estimated by titrating a $10 \mathrm{~mL} \mathrm{NaOH}$ solution plus three drops of phenolphthalein with $0.5 \mathrm{~mol} \mathrm{~L}^{-1} \mathrm{HCl}$ solution.

After the incubation period, $18 \mathrm{~g}$ of soil were taken from each jar to determine microbial biomass (MBC) following the methodology described by Vance et al.

Table 1. Chemical characteristics of soil samples collected at $\mathbf{0 - 1 0} \mathbf{~ c m}$ depth in the municipality of Cajuri-Minas Gerais, Brazil in 2011.

\begin{tabular}{|c|c|c|c|c|c|c|c|c|c|c|c|c|}
\hline $\begin{array}{l}\text { Soil fertility } \\
\text { management } \\
\text { systems }\end{array}$ & $\mathrm{pH}$ & $\mathrm{P}$ & $\mathrm{K}$ & $\mathrm{Ca}^{2+}$ & $\mathrm{Mg}^{2+}$ & $\mathrm{Al}^{3+}$ & $\mathrm{H}+\mathrm{Al}$ & SB & ECEC & $\mathrm{V}$ & $\mathrm{m}$ & $\mathrm{OM}$ \\
\hline & & \multicolumn{2}{|c|}{$-\mathrm{mg} \mathrm{dm}^{-3}-$} & 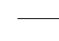 & 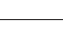 & $-\mathrm{c}$ & $\mathrm{dm}^{-3}$ & & - & $\%$ & & dag $\mathrm{kg}^{-1}$ \\
\hline SF & 5.9 & 8.6 & 71 & 3.8 & 1.5 & 0.0 & 4.79 & 5.48 & 5.48 & 53 & 0 & 3.3 \\
\hline $\mathrm{LF}$ & 5.9 & 10.3 & 74 & 3.8 & 1.1 & 0.0 & 5.12 & 5.09 & 5.09 & 50 & 0 & 2.8 \\
\hline NF & 4.8 & 11.6 & 70 & 1.1 & 0.6 & 0.8 & 9.73 & 1.88 & 2.68 & 16 & 30 & 3.7 \\
\hline NN & 4.5 & 2.2 & 36 & 0.3 & 0.2 & 1.9 & 11.72 & 0.59 & 2.49 & 5 & 76 & 3.5 \\
\hline
\end{tabular}

SF: Acidity correction with calcium and magnesium silicate + fertilization; LF: acidity correction with limestone + fertilization; NF: no acidity correction + fertilization; NN: no acidity correction + no fertilization; pH: active acidity in water; $\mathrm{H}+\mathrm{Al}$ : potential acidity; SB: sum of bases; ECEC: effective cation exchangeable capacity; V: base saturation; m: Al saturation; OM: organic matter. 
(1987) and modified by Islam and Weil (1998). From the C-CO $\mathrm{CO}_{2}$ evolution and MBC values, $q \mathrm{CO}_{2}\left(\mu \mathrm{g} \mathrm{C}-\mathrm{CO}_{2} \mu \mathrm{g}^{-1}\right.$ $\mathrm{MBC} \mathrm{d}^{-1}$ ) was determined (Anderson and Domsch, 1993).

To interpret results, data were subjected to ANOVA by the F-test at $5 \%$ error probability. We conducted the unfolding of significant interactions and also opted to present the study of comparisons of each factor alone, and means were compared by Duncan's test $(\mathrm{p}<0.05)$.

Orthogonal contrasts were established for comparisons between monocultures and competition arrangements tested by t-tests. The contrasts of $\mathrm{Y}_{1}$ to $\mathrm{Y}_{5}$ were designed to compare the effects of competition and compare the means obtained for weeds cultivated in monoculture with the means of the respective plants in competition with corn. The contrast $\mathrm{Y}_{6}$ was set to compare the isolated effect of all the species with the combinations established between corn and weed, and contrast $\mathrm{Y}_{7}$ was set to compare the effect of the presence of species compared with uncultivated soils in these variables.

\section{RESULTS AND DISCUSSION}

The microbiological attributes of the soil behaved differently in monocultures, competition arrangements, and soil fertility management systems. The interaction between species and soil fertility management was significant ( $\mathrm{p}$ $<0.05)$ for the microbial biomass $\mathrm{C}$ (MBC), respiration rate $(\mathrm{RR})$, and metabolic quotient $\left(q \mathrm{CO}_{2}\right)$ variables. There was high variability in the results for the variable $\mathrm{MBC}$ regarding the evaluated factors. Several studies have found differences in the content of MBC due to the plant cycle, adding crop residues, tillage systems, and crop rotation (Franchini et al., 2007; Ferreira et al., 2010).

In the isolated study of soil fertility management systems, a decreasing trend of MBC was observed in those systems that did not apply acidity correction although MBC was not significantly different from soil with fertilizer + limestone application (Table 2). The unfavorable nutritional conditions and high Al saturation of these soils can reduce $\mathrm{C}$ intake by plants and result in soils that can retain $\mathrm{C}$, present lower exudation, and thus sustain lower microbial biomass (MB). Under the combined action of the two factors, soil with calcium and magnesium silicate + fertilization $(\mathrm{SF})$ or limestone + fertilization (LF) had similar MBC values. As for the species effect, higher MBC was associated with B. pilosa (Table 2). Plants have a varied capacity to stimulate microbial biomass, which is closely related to the chemical characteristics of soil, suggesting a possible strategy of the plant to tolerate or adapt to certain conditions.

Weeds had higher microbial biomass than corn in the SF soil (Table 2), indicating their greater dependence on soil microbes. This fact was also reported by Santos et al. (2012), who evaluated the growth and accumulation of macro- and micronutrients in eight weeds and in corn and beans grown in fumigated and non-fumigated soil; they noted that bean and corn crops were less affected by soil sterilization than weeds, thus suggesting a possible dependence of the latter to edaphic microorganisms.

The crop with $B$. pilosa, regardless of fertility management, showed high MBC values, especially in relation to other species (Table 2). This finding can partly explain why this species can be established in different edaphic conditions, provide greater competitive ability, and be able to exude the amount of $\mathrm{C}$ sufficient to sustain high MB. According to Santos and Cury (2011), $B$. pilosa has a high potential for nutrient accumulation, and regulation of attraction and/or repulsion of microorganisms; this is probably due to the characteristic of roots exuding a variety of compounds, which make the

Table 2. Microbial biomass carbon (MBC) of soil based on different soil fertility management systems, monocultures, and simultaneous cultivation of corn with weed species.

\begin{tabular}{|c|c|c|c|c|c|}
\hline \multirow[b]{2}{*}{ Crops } & \multicolumn{5}{|c|}{ Soil fertility management systems } \\
\hline & SF & LF & NF & $\mathrm{NN}$ & Mean \\
\hline \multicolumn{6}{|l|}{ Monocultures } \\
\hline Zea mays & $123.51 \mathrm{Bb}$ & $189.12 \mathrm{ABbc}$ & $293.33 \mathrm{Aa}$ & $165.96 \mathrm{Bbc}$ & $192.98 b$ \\
\hline Urochloa brizantha & $339.65 \mathrm{Aa}$ & $382.11 \mathrm{Aa}$ & $191.58 \mathrm{Bab}$ & $96.49 \mathrm{Bc}$ & $252.46 \mathrm{ab}$ \\
\hline Ipomoea grandifolia & $304.91 \mathrm{Aa}$ & $204.56 \mathrm{ABbc}$ & $115.79 \mathrm{Bb}$ & $196.84 \mathrm{ABbc}$ & $205.52 b$ \\
\hline Hyptis suaveolens & $324.21 \mathrm{Aa}$ & $260.53 \mathrm{Abc}$ & $108.07 \mathrm{Bb}$ & $239.30 \mathrm{Aab}$ & $233.03 b$ \\
\hline Conyza canadensis & $270.18 \mathrm{Aa}$ & $165.97 \mathrm{Abc}$ & 185.26Aab & $220.00 \mathrm{Ab}$ & $210.35 b$ \\
\hline Bidens pilosa & $250.88 \mathrm{Aa}$ & 283.68Aab & $274.04 \mathrm{Aa}$ & $351.23 \mathrm{Aa}$ & $289.96 \mathrm{a}$ \\
\hline No crop & $231.58 \mathrm{Aa}$ & $158.25 \mathrm{Ac}$ & $262.46 \mathrm{Aa}$ & 268.77Aab & $230.26 b$ \\
\hline Mean & $263.56 \mathrm{~A}$ & $234.89 \mathrm{AB}$ & 204.36B & 219.80B & \\
\hline \multicolumn{6}{|l|}{ Competition arrangements } \\
\hline Zea mays & $123.51 \mathrm{Bb}$ & $189.12 \mathrm{ABbc}$ & 293.33Aab & $165.96 \mathrm{Bb}$ & $192.98 \mathrm{c}$ \\
\hline Z. mays $+U$. brizantha & $239.30 \mathrm{Aa}$ & $270.18 \mathrm{Aab}$ & $320.35 \mathrm{Aa}$ & $351.23 \mathrm{Aa}$ & $295.26 \mathrm{a}$ \\
\hline Z. mays $+I$. grandifolia & $339.65 \mathrm{Aa}$ & $131.23 \mathrm{Bc}$ & $173.68 \mathrm{Bc}$ & $289.47 \mathrm{Aa}$ & $233.51 b c$ \\
\hline Z. mays $+H$. suaveolens & $328.07 \mathrm{Aa}$ & $320.35 \mathrm{Aa}$ & $204.56 \mathrm{Bbc}$ & $331.93 \mathrm{Aa}$ & $296.23 \mathrm{a}$ \\
\hline Z. mays $+C$. canadensis & 335.79Aa & $169.83 \mathrm{Bbc}$ & $165.96 \mathrm{Bc}$ & $144.74 \mathrm{Bb}$ & $204.08 b c$ \\
\hline Z. mays $+B$. pilosa & $312.63 \mathrm{Aa}$ & 235.44ABabc & $162.11 \mathrm{Bc}$ & $331.93 \mathrm{Aa}$ & $260.53 \mathrm{ab}$ \\
\hline Mean & $279.82 \mathrm{~A}$ & 219.36B & $220.00 \mathrm{~B}$ & $269.21 \mathrm{~A}$ & \\
\hline$\overline{\mathrm{CV}, \%}$ & & & 27.10 & & \\
\hline
\end{tabular}

SF: Acidity correction with calcium and magnesium silicate + fertilization; LF: acidity correction with limestone + fertilization; NF: no acidity correction + fertilization; NN: no acidity correction + no fertilization; CV: coefficient of variation.

Means followed by the same uppercase letter in the same row and the same lowercase letter in the same column do not differ by Duncan's test (p $>0.05$ ). 
rhizosphere a highly regulated environment that is adapted to environmental changes. In general, the ratio of corn and weed depends on the species involved and soil fertility management. Each combination of crop, weed, and soil fertility management system can result in different values for the microbiological variables, thus highlighting the complexity of these interactions. According to Baudoin et al. (2003), most studies of monoculture pot-grown plants revealed that specific groups of microorganisms were associated with the rhizosphere. However, Singh et al. (2004) reported that field trials involving a mixed community of plants found contradictory results; some trials found no such selection in the rhizosphere while others showed a strong correlation between plants and the soil microbial community.

When analyzing $\mathrm{MBC}$ in competition arrangements as an isolated effect of soil fertility management, we observed higher MBC in those arrangements with added calcium and magnesium silicate + fertilization (SF) and no correction of acidity + no fertilization (NN), following the same trend in most arrangements (Table 2). The result for SF soil is consistent with high MBC values found in monoculture plants and possibly shows a synergistic action of the simultaneous cultivation of species on the MBC variable. However, the result in $\mathrm{NN}$ was inconsistent with the overall effect (Table 2), which may reflect a strategy of most arrangements in stimulating microbial biomass to enhance nutrient acquisition in the soil.

By studying the effect of species in SF and NN soils, there was a significant reduction in $\mathrm{MBC}$ for corn in monoculture with respect to mixed cultures (Table 2). This result reinforces the fact that the diversity of soil coverage can also promote composition and microbial biomass due to the greater diversity of organic compounds secreted; in turn, it promotes the growth of microorganisms with various nutritional requirements (Moreira and Siqueira, 2006). Contrary results were observed in NF soil where there was a decrease in MBC of arrangements in relation to $Z$. mays monoculture, with the exception of $Z$. mays $+U$. brizantha (Table 2). In response to the stress imposed by competition, there can be no release of allelopathic substances by plants, which inhibit microorganisms to discourage more dependent species and gain competitive advantage. Zea mays $+U$. brizantha was able to sustain a high microbial biomass compared with other arrangements in the four soil conditions (Table 2), which indicates, in general, a greater tendency toward $\mathrm{C}$ accumulation in the soil. This result is very interesting in the context of croppasture integration, considering that these two species are widely used as system components.

When comparing the arrangements with their respective weed in monoculture, significant values were found with reduced $\mathrm{MBC}$ in $Z$. mays $+U$. brizantha and $Z$. mays $+B$. pilosa in the LF and NF soil, respectively (Table 3). The associated reduction in microbial biomass can be due to the strategy of plants to retain $\mathrm{C}$ as a result of competition and sharing less $\mathrm{C}$ to be exuded, thereby reducing $\mathrm{MBC}$. Another possibility is the release of substances with allelopathic effects, thus decreasing microbial biomass to inhibit growth of other plants that are more dependent on soil microorganisms. Conversely, MBC increased due to competition between $Z$. mays $+U$. brizantha in soils without acidity correction (Table 3 ), which suggests a synergistic action promoted by simultaneous cultivation of these two species, and indicates that their presence in less fertile soils can be important to increase levels of organic $\mathrm{C}$ and microbial biomass in soil. These results show that there is a modification of the quantity of soil microorganisms depending on the fertility management system and plant species. Greater MBC was attributed to the presence of species in monoculture in LF soil as compared with no crop (Table 3). The diversity of species represented by competition arrangements had higher MB than monocultures in NN soil (Table 3), possibly due to the greater quantity and diversity of released exudates.

Mean values of respiration rate (RR) of soil samples under the effect of soil fertility management systems and monoculture of weeds and corn are presented in Table 4. In general, as an isolated effect of fertility management, NN soil had lower RR, which demonstrates the importance of acidity correction and fertilization to stimulate microbial activity. Rangel-Castro et al. (2005),

Table 3. Estimates of contrasts for microbial biomass carbon (MBC) under different soil fertility management systems and crops.

\begin{tabular}{|c|c|c|c|c|}
\hline \multirow[b]{2}{*}{ Contrasts } & \multicolumn{4}{|c|}{ Estimates for CBM in soil fertility management systems } \\
\hline & SF & LF & NF & NN \\
\hline $\mathrm{Y}_{1}=\mathrm{m}_{\mathrm{U}}-\mathrm{m}_{\mathrm{ZU}}^{1}$ & $1.87^{\mathrm{ns}}$ & $2.09^{*}$ & $-2.41^{*}$ & $-4.76^{* *}$ \\
\hline $\mathrm{Y}_{2}=\mathrm{m}_{\mathrm{I}}-\mathrm{m}_{\mathrm{ZI}}$ & $-0.65^{\mathrm{ns}}$ & $1.37^{\mathrm{ns}}$ & $-1.08^{\mathrm{ns}}$ & $-1.73^{\text {ns }}$ \\
\hline $\mathrm{Y}_{3}=\mathrm{m}_{\mathrm{H}}-\mathrm{m}_{\mathrm{ZH}}$ & $-0.07^{\mathrm{ns}}$ & $-1.12^{\mathrm{ns}}$ & $-1.80^{\mathrm{ns}}$ & $-1.73^{\mathrm{ns}}$ \\
\hline $\mathrm{Y}_{4}=\mathrm{m}_{\mathrm{C}}-\mathrm{m}_{\mathrm{ZC}}$ & $-1.23^{\mathrm{ns}}$ & $-0.07^{\mathrm{ns}}$ & $0.36^{\mathrm{ns}}$ & $1.41^{\mathrm{ns}}$ \\
\hline $\mathrm{Y}_{5}=\mathrm{m}_{\mathrm{B}}-\mathrm{m}_{\mathrm{ZB}}$ & $-1.15^{\mathrm{ns}}$ & $0.90^{\mathrm{ns}}$ & $2.09^{*}$ & $0.36^{\mathrm{ns}}$ \\
\hline $\mathrm{Y}_{6}=($ monocultures $)-(\text { competition arrangements })^{2}$ & $-1.84^{\mathrm{ns}}$ & $0.97^{\mathrm{ns}}$ & $1.44^{\mathrm{ns}}$ & $-3.41^{* *}$ \\
\hline $\mathrm{Y}_{7}=($ monocultures $)-\mathrm{m}_{\mathrm{NC}}{ }^{3}$ & $0.91^{\mathrm{ns}}$ & $2.18^{*}$ & $-1.66^{\mathrm{ns}}$ & $-1.40^{\mathrm{ns}}$ \\
\hline
\end{tabular}

SF: Acidity correction with calcium and magnesium silicate + fertilization; LF: acidity correction with limestone + fertilization; NF: no acidity correction + fertilization; NN: no acidity correction + no fertilization.

** * Significant at 0.01 and 0.05 probability levels, respectively; ${ }^{\text {ns: }}$ non significant.

${ }^{1} \mathrm{~m}$ : mean; Z: Zea mays monoculture; U: Urochloa brizantha monoculture; I: Ipomoea grandifolia monoculture; H: Hyptis suaveolens monoculture; C: Conyza canadensis monoculture; B: Bidens pilosa monoculture; ZU: Z. mays+U. brizantha; ZI: Z. mays+I. grandifolia; ZH: Z. mays+H. suaveolens; ZC: Z. mays+C. canadensis; ZB: Z. mays + B. pilosa; NC: no crop.

${ }^{2} \mathrm{Y}_{6}=\left(\mathrm{m}_{\mathrm{Z}}+\mathrm{m}_{\mathrm{U}}+\mathrm{m}_{\mathrm{I}}+\mathrm{m}_{\mathrm{H}}+\mathrm{m}_{\mathrm{C}}+\mathrm{m}_{\mathrm{B}}\right)-\left(\mathrm{m}_{\mathrm{ZU}}+\mathrm{m}_{\mathrm{ZI}}+\mathrm{m}_{\mathrm{ZH}}+\mathrm{m}_{\mathrm{ZC}}+\mathrm{m}_{\mathrm{ZB}}\right)$

${ }^{3} Y_{7}=\left(m_{Z}+m_{U}+m_{I}+m_{H}+m_{C}+m_{B}\right)-m_{N C}$. 
Table 4. Respiration rate (RR) of soil for different fertility management systems, monocultures, and simultaneous cultivation of corn and weed species.

\begin{tabular}{|c|c|c|c|c|c|}
\hline \multirow[b]{2}{*}{ Crops } & \multicolumn{5}{|c|}{ Soil fertility management systems } \\
\hline & SF & LF & $\mathrm{NF}$ & $\mathrm{NN}$ & Mean \\
\hline \multicolumn{6}{|l|}{ Monocultures } \\
\hline Zea mays & 82.99ABab & 69.16BCab & $101.81 \mathrm{Aa}$ & $55.89 \mathrm{Cbc}$ & $77.46 \mathrm{a}$ \\
\hline Urochloa brizantha & $87.55 \mathrm{Aab}$ & 76.15ABab & 79.28ABabc & $55.78 \mathrm{Bbc}$ & $74.69 \mathrm{a}$ \\
\hline Ipomoea grandifolia & 84.70Aab & $93.17 \mathrm{Aa}$ & $74.43 \mathrm{Abc}$ & $77.88 \mathrm{Aab}$ & $82.55 \mathrm{a}$ \\
\hline Hyptis suaveolens & $61.32 \mathrm{Ab}$ & $83.42 \mathrm{Aab}$ & $64.90 \mathrm{Ac}$ & 76.71Aab & $71.59 \mathrm{a}$ \\
\hline Conyza canadensis & $75.72 \mathrm{Aab}$ & $84.41 \mathrm{Aab}$ & 71.19Abc & $95.61 \mathrm{Aa}$ & $81.73 \mathrm{a}$ \\
\hline Bidens pilosa & 75.71 Aab & 84.17Aab & 84.70Aabc & $46.71 \mathrm{Bc}$ & $72.83 \mathrm{a}$ \\
\hline No crop & $97.53 \mathrm{Aa}$ & $60.60 \mathrm{Bb}$ & $95.75 \mathrm{Aab}$ & $66.31 \mathrm{Bbc}$ & $80.05 \mathrm{a}$ \\
\hline Mean & $80.79 \mathrm{~A}$ & $78.72 \mathrm{~A}$ & $81.72 \mathrm{~A}$ & 67.84B & \\
\hline \multicolumn{6}{|l|}{ Competition arrangements } \\
\hline Zea mays & $82.99 \mathrm{ABb}$ & 69.16BCab & $101.81 \mathrm{Aa}$ & $55.89 \mathrm{Ca}$ & $77.46 \mathrm{ab}$ \\
\hline Z. mays $+U$. brizantha & $110.65 \mathrm{Aa}$ & $80.08 \mathrm{Bab}$ & $82.07 \mathrm{Bab}$ & $76.71 \mathrm{Ba}$ & $87.38 \mathrm{a}$ \\
\hline Z. mays $+I$. grandifolia & $76.14 \mathrm{Ab}$ & $74.95 \mathrm{Aab}$ & $80.08 \mathrm{Aab}$ & $81.28 \mathrm{Aa}$ & $78.11 \mathrm{ab}$ \\
\hline Z. mays $+H$. suaveolens & $78.14 \mathrm{ABb}$ & $87.92 \mathrm{Aa}$ & $58.12 \mathrm{Bb}$ & 79.67ABa & $75.96 \mathrm{ab}$ \\
\hline Z. mays $+C$. canadensis & $72.29 \mathrm{Ab}$ & $78.28 \mathrm{Aab}$ & $61.54 \mathrm{Ab}$ & $63.74 \mathrm{Aa}$ & $68.96 \mathrm{~b}$ \\
\hline Z. mays $+B$. pilosa & $87.13 \mathrm{Ab}$ & $60.66 \mathrm{Bb}$ & $92.57 \mathrm{Aa}$ & 78.86ABa & $79.80 \mathrm{ab}$ \\
\hline Mean & $84.56 \mathrm{~A}$ & $75.17 \mathrm{AB}$ & $79.36 \mathrm{AB}$ & $72.69 \mathrm{~B}$ & \\
\hline$\overline{\mathrm{CV}, \%}$ & & & 18.03 & & \\
\hline
\end{tabular}

SF: Acidity correction with calcium and magnesium silicate + fertilization; LF: acidity correction with limestone + fertilization; NF: no acidity correction + fertilization; NN: no acidity correction + no fertilization; CV: coefficient of variation.

Means followed by the same uppercase letter in the same row and the same lowercase letter in the same column do not differ by Duncan's test ( $\mathrm{p}>0.05$ ).

through combined denaturing gradient gel electrophoresis (DGGE, ribosomal genes amplified by PCR) techniques and probing with ${ }^{13} \mathrm{C}$ isotope, showed that limed soils had a microbial community (Archaea, Bacteria, and Fungi) that was more active (use of recently exuded compounds with ${ }^{13} \mathrm{C}$ ) and complex than soils without acidity correction.

The presence of weeds and corn changed the RR, suggesting that plants manipulate microbial activity in terms of soil fertility management. A behavior similar to the general effect of soil fertility management can be observed under the influence of species with the lowest RR or similar to the lowest in NN soil (Table 4). In this soil condition, the growth and development of some species was affected due to the characteristics of low fertility and high $\mathrm{Al}$ saturation, which may have significantly affected the deposition of compounds that stimulate soil microbial activity.

In general, the maintenance of the same RR associated with the species was noted, indicating that the increase in $\mathrm{C}-\mathrm{CO}_{2}$ was similar among them. Similarly, in soils receiving a source of acidity correction, biological activity associated with the species was similar (Table 4). In contrast, in those soils without acidity correction, wide RR variations were found, indicating that species in these ground conditions have a more pronounced role in biological activity (Table 4).

Uncultivated soils that received calcium and magnesium silicate + fertilization $(\mathrm{SF})$ or limestone + fertilization (LF) had high and low RR values, respectively (Table 4). In uncultivated soils, fewer microorganisms and lower metabolic activity are expected in relation to cultivated soils because there is no supply of $\mathrm{C}$ and energy via root exudation of plants as observed in LF (Sandmann and Loos, 1984). However, increased C-CO $\mathrm{CO}_{2}$ production in SF soil can be directly related to the high $\mathrm{MBC}$ value (Table 2) or be a result of an imbalance in the microbial community due to non-supply of growth factors, thereby inhibiting certain microbial populations whose dead cells would be used by the active microbial biomass as a $\mathrm{C}$ source and energy for their metabolism (Sakamoto and Obo, 1994). We observed the same general effect of soil fertility management associated with species in monoculture (Table 4). Significant differences between SF and LF soils can be observed and with superiority of the former on biological activity (Table 4). In the soil, calcium and magnesium silicates are used as fertilizers and correctives that raise $\mathrm{pH}$ and base saturation. In the plant, Si has beneficial effects (Ma et al., 2001) primarily related to increased resistance to pests and diseases (Goussain et al., 2002; Seebold et al., 2004), increased plant resistance to $\mathrm{Al}$ excess (Neumann and Nieden, 2001; Liang et al., 2007), and increased photosynthesis efficiency (Gao et al., 2004). Nevertheless, no studies in the literature have recorded the effects of adding Si to the soil on microbial activity or on groups of microorganisms beneficial to plants, thus complicating the interpretation of this result. The Si can be exerting a direct influence on the microbiota or indirectly via the plant.

As for species, simultaneous cultivation of corn and weeds caused changes in RR and only in NN soil under the action of the factors; there was no significant effect ( $p$ $>0.05$ ) among the arrangements (Table 4). Similar to the variable MBC, the mixed system formed by $Z$. mays $+U$. brizantha showed high microbial activity compared with other arrangements in the four soil fertility management systems (Table 4).

In the orthogonal contrasts, $\mathrm{RR}$ decreased in $\mathrm{LF}$ and $\mathrm{NN}$ soils when grown with $Z$. mays $+B$. pilosa and Z. mays $+C$. canadensis, respectively, and increased microbial activity in SF and NN soils in the presence of $Z$. mays $+U$. brizantha and Z. mays $+B$. pilosa, respectively (Table 5). 
Table 5. Estimates of contrasts for respiration rate (RR) under different soil fertility management systems and crops.

\begin{tabular}{|c|c|c|c|c|}
\hline \multirow[b]{2}{*}{ Contrasts } & \multicolumn{4}{|c|}{ Estimates for RR in soil fertility management systems } \\
\hline & SF & LF & NF & NN \\
\hline $\mathrm{Y}_{1}=\mathrm{m}_{\mathrm{U}}-\mathrm{m}_{\mathrm{ZU}}{ }^{1}$ & $-2.02^{*}$ & $-0.34^{\mathrm{ns}}$ & $-0.24^{\mathrm{ns}}$ & $-1.83^{\text {ns }}$ \\
\hline $\mathrm{Y}_{2}=\mathrm{m}_{\mathrm{I}}-\mathrm{m}_{\mathrm{ZI}}$ & $0.75^{\mathrm{ns}}$ & $1.60^{\mathrm{ns}}$ & $-0.47^{\mathrm{ns}}$ & $-0.30^{\mathrm{ns}}$ \\
\hline $\mathrm{Y}_{3}=\mathrm{m}_{\mathrm{H}}-\mathrm{m}_{\mathrm{ZH}}$ & $-1.47^{\mathrm{ns}}$ & $-0.39^{\text {ns }}$ & $0.59^{\text {ns }}$ & $-0.26^{\mathrm{ns}}$ \\
\hline $\mathrm{Y}_{4}=\mathrm{m}_{\mathrm{C}}-\mathrm{m}_{\mathrm{ZC}}$ & $0.30^{\mathrm{ns}}$ & $0.54^{\mathrm{ns}}$ & $0.84^{\mathrm{ns}}$ & $2.79^{* *}$ \\
\hline $\mathrm{Y}_{5}=\mathrm{m}_{\mathrm{B}}-\mathrm{m}_{\mathrm{ZB}}$ & $-1.00^{\mathrm{ns}}$ & $2.06^{*}$ & $-0.69^{\text {ns }}$ & $-2.82^{* *}$ \\
\hline $\mathrm{Y}_{6}=($ monocultures $)-(\text { competition arrangements })^{2}$ & $-0.02^{\mathrm{ns}}$ & $1.10^{\mathrm{ns}}$ & $0.92^{\mathrm{ns}}$ & $-1.63^{\text {ns }}$ \\
\hline $\mathrm{Y}_{7}=($ monocultures $)-\mathrm{m}_{\mathrm{NC}}{ }^{3}$ & $-1.97^{\mathrm{ns}}$ & $2.42^{*}$ & $-1.88^{\mathrm{ns}}$ & $0.20^{\mathrm{ns}}$ \\
\hline
\end{tabular}

SF: Acidity correction with calcium and magnesium silicate + fertilization; LF: acidity correction with limestone + fertilization; NF: no acidity correction + fertilization; NN: no acidity correction + no fertilization.

${ }^{* *},{ }^{*}$ Significant at 0.01 and 0.05 probability levels, respectively; ${ }^{\text {ns: }}$ non significant.

${ }^{1}$ m: mean; Z: Zea mays monoculture; U: Urochloa brizantha monoculture; I: Ipomoea grandifolia monoculture; H: Hyptis suaveolens monoculture; C: Conyza canadensis monoculture; B: Bidens pilosa monoculture; ZU: Z. mays+U. brizantha; ZI: Z. mays+I. grandifolia; ZH: Z. mays+H. suaveolens; ZC: Z. mays+C. canadensis; ZB: Z. mays + B. pilosa; NC: no crop.

${ }^{2} \mathrm{Y}_{6}=\left(\mathrm{m}_{\mathrm{Z}}+\mathrm{m}_{\mathrm{U}}+\mathrm{m}_{\mathrm{I}}+\mathrm{m}_{\mathrm{H}}+\mathrm{m}_{\mathrm{C}}+\mathrm{m}_{\mathrm{B}}\right)-\left(\mathrm{m}_{\mathrm{ZU}}+\mathrm{m}_{\mathrm{ZI}}+\mathrm{m}_{\mathrm{ZH}}+\mathrm{m}_{\mathrm{ZC}}+\mathrm{m}_{\mathrm{ZB}}\right)$.

${ }^{3} Y_{7}=\left(m_{Z}+m_{U}+m_{I}+m_{H}+m_{C}+m_{B}\right)-m_{N C}$.

Soil microorganisms can be favorably used by the plants in an attempt to minimize competition and provide greater nutrient acquisition, particularly in less favorable soil nutritional conditions. These strategies vary according to species and applied soil fertility management and confirm the hypothesis that plants, alone or in competition, manipulate soil microorganisms. As for MBC (Table 3), soils receiving surface application of limestone and crops had a significantly more active community than those without cultivation (Table 5).

For the overall mean of soil fertility management, lower efficiency of $\mathrm{MB}$ in the use of $\mathrm{C}$ and energy $\left(>q \mathrm{CO}_{2}\right)$ was observed in NF soil (Table 6) and this implies that this soil has a higher susceptibility to $\mathrm{C}$ losses. The $q \mathrm{CO}_{2}$ is a measure of equilibrium of the system and was proposed by Anderson and Domsch (1993) as an adaptation of the theory of "bioenergetic development of ecosystems", which predicts that the closer it is to equilibrium, less energy is required to maintain the microbial cell, and the further it is to equilibrium, higher specific activity is required. Thus, a low $q \mathrm{CO}_{2}$ indicates economy in energy use, and presumably reflects an environment that is more stable and closer to its equilibrium state; in contrast, high values indicate ecosystems subjected to stress conditions or disorder (Tótola and Chaer, 2002) andindicate less conservationist systems of soil organic matter (SOM). For corn, SF soil had higher respiration per biomass unit. However, for weeds in monoculture, SF soils showed similar or higher SOM conservation than LF soils (Table 6). Soil microbiota associated with different species showed the same activity level per biomass unit, but considering interactions between these plants and soil fertility management systems, activity was substantially altered. The SF soil showed lower $\mathrm{C}-\mathrm{CO}_{2}$ loss and greater $\mathrm{C}$ incorporation in microbial cells $(<$ $\left.q \mathrm{CO}_{2}\right)$ in the presence of weeds and uncultivated soils compared with soils cultivated with corn in monoculture (Table 6). This indicates that corn monoculture is the least favorable system for long-term $\mathrm{C}$ conservation and suggests a reduced need for oxidation presented by

Table 6. Metabolic quotient $\left(q \mathrm{CO}_{2}\right)$ of the soil based on different soil fertility management systems, monocultures, and simultaneous cultivation of corn and weed species.

\begin{tabular}{|c|c|c|c|c|c|}
\hline \multirow[b]{2}{*}{ Crops } & \multicolumn{5}{|c|}{ Soil fertility management systems } \\
\hline & SF & LF & NF & $\mathrm{NN}$ & Mean \\
\hline \multicolumn{6}{|l|}{ Monocultures } \\
\hline Zea mays & $0.67 \mathrm{Aa}^{2}$ & $0.40 \mathrm{Bab}$ & $0.35 \mathrm{Bc}$ & $0.40 \mathrm{Bb}$ & $0.46 \mathrm{a}$ \\
\hline Urochloa brizantha & $0.27 \mathrm{BCbc}$ & $0.21 \mathrm{Cb}$ & $0.44 \mathrm{Bbc}$ & $0.74 \mathrm{Aa}$ & $0.42 \mathrm{a}$ \\
\hline Ipomoea grandifolia & $0.28 \mathrm{Cbc}$ & $0.48 \mathrm{ABa}$ & $0.66 \mathrm{Aa}$ & $0.40 \mathrm{BCb}$ & $0.45 \mathrm{a}$ \\
\hline Hyptis suaveolens & $0.19 \mathrm{Bc}$ & $0.32 \mathrm{Bab}$ & $0.61 \mathrm{Aab}$ & $0.32 \mathrm{Bbc}$ & $0.36 \mathrm{a}$ \\
\hline Conyza canadensis & $0.28 \mathrm{Bbc}$ & $0.53 \mathrm{Aa}$ & $0.40 \mathrm{ABc}$ & $0.44 \mathrm{ABb}$ & $0.41 \mathrm{a}$ \\
\hline Bidens pilosa & $0.30 \mathrm{Abc}$ & $0.31 \mathrm{Aab}$ & $0.33 \mathrm{Ac}$ & $0.15 \mathrm{Ac}$ & $0.28 \mathrm{a}$ \\
\hline No crop & $0.42 \mathrm{Ab}$ & $0.42 \mathrm{Aab}$ & $0.38 \mathrm{Ac}$ & $0.26 \mathrm{Abc}$ & $0.37 \mathrm{a}$ \\
\hline Mean & $0.34 \mathrm{~B}$ & $0.38 \mathrm{AB}$ & $0.45 \mathrm{~A}$ & $0.39 \mathrm{AB}$ & \\
\hline \multicolumn{6}{|l|}{ Competition arrangements } \\
\hline Zea mays & $0.67 \mathrm{Aa}$ & $0.40 \mathrm{Bb}$ & $0.35 \mathrm{Bb}$ & $0.40 \mathrm{Bab}$ & $0.46 \mathrm{a}$ \\
\hline Z. mays $+U$. brizantha & $0.46 \mathrm{Ab}$ & $0.30 \mathrm{ABb}$ & $0.27 \mathrm{ABb}$ & $0.23 \mathrm{Bb}$ & $0.31 \mathrm{bc}$ \\
\hline Z. mays $+I$. grandifolia & $0.24 \mathrm{Cc}$ & $0.61 \mathrm{Aa}$ & $0.46 \mathrm{ABab}$ & $0.30 \mathrm{BCab}$ & $0.40 \mathrm{ab}$ \\
\hline Z. mays $+H$. suaveolens & $0.24 \mathrm{Ac}$ & $0.29 \mathrm{Ab}$ & $0.34 \mathrm{Ab}$ & $0.25 \mathrm{Ab}$ & $0.28 \mathrm{c}$ \\
\hline Z. mays $+C$. canadensis & $0.22 \mathrm{Bc}$ & $0.47 \mathrm{Aab}$ & $0.37 \mathrm{ABb}$ & $0.46 \mathrm{Aa}$ & $0.38 \mathrm{abc}$ \\
\hline Z. mays $+B$. pilosa & $0.29 \mathrm{Bbc}$ & $0.27 \mathrm{Bb}$ & $0.58 \mathrm{Aa}$ & $0.24 \mathrm{Bb}$ & $0.34 b c$ \\
\hline Mean & $0.35 \mathrm{~A}$ & $0.39 \mathrm{~A}$ & $0.40 \mathrm{~A}$ & $0.31 \mathrm{~A}$ & \\
\hline $\mathrm{CV}, \%$ & & & 31.31 & & \\
\hline
\end{tabular}

SF: Acidity correction with calcium and magnesium silicate + fertilization; LF: acidity correction with limestone + fertilization; NF: no acidity correction + fertilization; NN: no acidity correction + no fertilization; CV: coefficient of variation.

Means followed by the same uppercase letter in the same row and the same lowercase letter in the same column do not differ by Duncan's test ( $\mathrm{p}>0.05$ ). 
microbiota associated with weeds to maintain a larger microbial biomass can be due to lower demand and/or higher acquisition efficiency of nutrients, and thus a lower rate of SOM mineralization.

Given the results observed in other soil fertility management systems for the $q \mathrm{CO}_{2}$ variable (Table $6)$, it is clear that the presence of weeds in certain soil conditions can be crucial to the maintenance of higher SOM conservation $\left(<q \mathrm{CO}_{2}\right)$, while the permanence of other weeds in certain soil conditions can stimulate oxidation of organic matter by soil microorganisms leading to loss $\left(>q \mathrm{CO}_{2}\right)$. Thus, from the point of view of soil conservation, the activity of soil microbes could be used as an auxiliary indicator in integrated weed management by considering the balance between the benefit that certain weeds can bring to soil conservation and the damage caused to crops.

Regarding $q \mathrm{CO}_{2}$ associated with simultaneous cultivation of weeds and corn (Table 6), Z. mays $+H$. suaveolens in the four soil fertility management systems was the mixed system that provided greater efficiency of associated microbiota and was the most conservative for organic matter.

All arrangements differed from monoculture Z. mays in SF soil (Table 6), with the last one presenting higher RR for the same biomass unit, which means that by stimulating organic matter degradation this system can cause large losses of organic C if it persists. In contrast, competition arrangements in this soil would have lower losses at the lower stimulus to oxidative processes. In other soil fertility management systems, other arrangements had higher $q \mathrm{CO}_{2}$ and, following the trend shown by the overall mean, indicate that arrangements among $Z$. mays $+I$. grandifolia and Z. mays $+C$. canadensis, as well as Z. mays in monoculture (Table 6) have a higher level of disturbance and lower energy savings. Zea mays $+U$. brizantha in $\mathrm{SF}$ soil and Z. mays $+B$. pilosa in $\mathrm{NF}$ soil stimulated microbial activity and degradation of SOM (Table 7) with increasing $q \mathrm{CO}_{2}$. The $Z$. mays $+I$. grandifolia and $Z$. mays $+H$. suaveolens arrangements in $\mathrm{NF}$ soil, and Z. mays $+U$. brizantha in $\mathrm{NN}$ soil improved efficiency of $\mathrm{C}$ incorporation to the soil in relation to the respective weeds in monoculture (Table 7). Similarly, in SF and NN soils, a positive and significant effect of mixed culture of species in relation to monocultures on microbial activity per biomass unit was detected.

\section{CONCLUSIONS}

Biomass and microbial activity are altered by plant species, coexistence, and soil fertility management. The sources of acidity correction (calcium and magnesium silicate; limestone) similarly influenced biomass and respiration rate of soil under most species in monoculture or under interference. For some crops, the Si source was better than limestone by providing greater energy efficiency to maintain microbial cells. The change in the microbial activity of soil can be a strategy used by the species to minimize the effects of competition.

\section{ACKNOWLEDGEMENTS}

The authors would like to thank Coordenação de Aperfeiçoamento de Pessoal de Nível Superior (CAPES), Conselho Nacional de Desenvolvimento Científico e Tecnológico (CNPq), and Fundação de Amparo à Pesquisa do Estado de Minas Gerais (FAPEMIG) for the scholarship and financial support for the research.

\section{LITERATURE CITED}

Anderson, T.H., and K.H. Domsch. 1993. The metabolic quotient for $\mathrm{CO}_{2}\left(q \mathrm{CO}_{2}\right)$ as a specific activity parameter to assess the effects of environmental conditions, such as $\mathrm{pH}$, on the microbial biomass of forest soils. Soil Biology and Biochemistry 25:393395. doi:10.1016/0038-0717(93)90140-7.

Bais, H.P., S.W. Park, T.L. Weir, R.M. Callaway, and J.M. Vivanco. 2004. How plants communicate using the underground information superhighway. Trends in Plant Science 9:26-32. doi:10.1016/j.tplants.2003.11.008.

Baudoin, E., E. Benizri, and A. Guckert. 2003. Impact of artificial root exudates on the bacterial community structure in bulk soil and maize rhizosphere. Soil Biology and Biochemistry 35:11831192. doi:10.1016/S0038-0717(03)00179-2.

Table 7. Estimates of contrasts for the metabolic quotient $\left(q \mathrm{CO}_{2}\right)$ of soil subjected to different soil fertility management systems and crops.

\begin{tabular}{|c|c|c|c|c|}
\hline \multirow[b]{2}{*}{ Contrasts } & \multicolumn{4}{|c|}{ Estimates for $q \mathrm{CO}_{2}$ in soil fertility management systems } \\
\hline & SF & LF & $\mathrm{NF}$ & $\mathrm{NN}$ \\
\hline $\mathrm{Y}_{1}=\mathrm{m}_{\mathrm{U}}-\mathrm{m}_{\mathrm{ZU}}^{1}$ & $-2.00^{*}$ & $-0.95^{\mathrm{ns}}$ & $1.79^{\mathrm{ns}}$ & $5.37^{* *}$ \\
\hline $\mathrm{Y}_{2}=\mathrm{m}_{\mathrm{I}}-\mathrm{m}_{\mathrm{ZI}}$ & $0.48^{\mathrm{ns}}$ & $-1.37^{\mathrm{ns}}$ & $2.11^{*}$ & $0.00^{\mathrm{ns}}$ \\
\hline $\mathrm{Y}_{3}=\mathrm{m}_{\mathrm{H}}-\mathrm{m}_{\mathrm{ZH}}$ & $-0.53^{\mathrm{ns}}$ & $0.32^{\mathrm{ns}}$ & $2.84^{* *}$ & $0.74^{\mathrm{ns}}$ \\
\hline $\mathrm{Y}_{4}=\mathrm{m}_{\mathrm{C}}-\mathrm{m}_{\mathrm{ZC}}$ & $0.63^{\mathrm{ns}}$ & $0.63^{\mathrm{ns}}$ & $0.32^{\text {ns }}$ & $-0.21^{\mathrm{ns}}$ \\
\hline $\mathrm{Y}_{5}=\mathrm{m}_{\mathrm{B}}-\mathrm{m}_{\mathrm{ZB}}$ & $1.37^{\mathrm{ns}}$ & $0.42^{\mathrm{ns}}$ & $-2.10^{*}$ & $-0.95^{\mathrm{ns}}$ \\
\hline $\mathrm{Y}_{6}=($ monocultures $)-(\text { competition arrangements })^{2}$ & $2.74^{* *}$ & $0.32^{\mathrm{ns}}$ & $1.50^{\mathrm{ns}}$ & $2.76^{* *}$ \\
\hline $\mathrm{Y}_{7}=($ monocultures $)-\mathrm{m}_{\mathrm{NC}^{3}}$ & $-1.20^{\mathrm{ns}}$ & $-0.61^{\mathrm{ns}}$ & $1.16^{\mathrm{ns}}$ & $2.02^{\mathrm{ns}}$ \\
\hline
\end{tabular}

SF: Acidity correction with calcium and magnesium silicate + fertilization; LF: acidity correction with limestone + fertilization; NF: no acidity correction + fertilization; NN: no acidity correction + no fertilization.

*** " Significant at 0.01 and 0.05 probability levels, respectively; ${ }^{n}$ : non significant.

${ }^{1} \mathrm{~m}$ : mean; Z: Zea mays monoculture; U: Urochloa brizantha monoculture; I: Ipomoea grandifolia monoculture; H: Hyptis suaveolens monoculture; C: Conyza canadensis monoculture; B: Bidens pilosa monoculture; ZU: Z. mays+U. brizantha; ZI: Z. mays+I. grandifolia; ZH: Z. mays+H. suaveolens; ZC: Z. mays+C. canadensis; $\mathrm{ZB}:$ Z. mays + B. pilosa; NC: no crop.

${ }^{2} Y_{6}=\left(m_{Z}+m_{U}+m_{I}+m_{H}+m_{C}+m_{B}\right)-\left(m_{Z U}+m_{Z I}+m_{Z H}+m_{Z C}+m_{Z B}\right)$.

${ }^{3} Y_{7}=\left(m_{Z}+m_{U}+m_{I}+m_{H}+m_{C}+m_{B}\right)-m_{N C}$. 
Carrera, L.M., J.S. Buyer, B. Vinyard, A.A. Abdul-Baki, L.J. Sikora, and J.R. Teasdale. 2007. Effects of cover crops, compost, and manure amendments on soil microbial community structure in tomato production systems. Applied Soil Ecology 37:247-255 doi:10.1016/j.apsoil.2007.08.003.

Ferreira, E.P.B., A.N. Dusi, J.L. Costa, G.R. Xavier, and N.G. Rumjanek. 2009. Assessing insecticide and fungicide effects on the culturable soil bacterial community by analyses of variance of their DGGE fingerprinting data. European Journal of Soil Biology 45:466-472. doi:10.1016/j.ejsobi.2009.07.003.

Ferreira, E.P.B., A.N. Dusi, G.R. Xavier, and N.G. Rumjanek. 2008. Rhizosphere bacterial communities of potato cultivars evaluated through PCR-DGGE profiles. Pesquisa Agropecuária Brasileira 43:605-612. doi:10.1590/S0100-204X2008000500008.

Ferreira, E.P.B., H.P. Santos, J.P. Costa, H. De-Polli, and N.G. Rumjanek. 2010. Microbial soil quality indicators under different crop rotations and tillage management. Revista Ciência Agronômica 41:177-183. doi:10.1590/S180666902010000200002.

Franchini, J.C., C.C. Crispino, R.A. Souza, E. Torres, and M. Hungria. 2007. Microbiological parameters as indicators of soil quality under various soil management and crop rotation systems in southern Brazil. Soil and Tillage Research 92:18-29. doi:10.1016/j.still.2005.12.010.

Gao, X., C. Zou, L. Wang, and F. Zhang. 2004. Silicon improves water use efficiency in maize plants. Journal of Plant Nutrition 27:1457-1470. doi:10.1081/PLN-200025865.

Goussain, M.M., J.C. Moraes, J.G. Carvalho, N.L. Nogueira, and M.L. Rossi. 2002. Effect of silicon application on corn plants upon the biological development of the fall armyworm Spodoptera frugiperda (J.E. Smith) (Lepidoptera: Noctuidae). Neotropical Entomology 31:305-310. doi:10.1590/S1519566X2002000200019.

Hirsch, A.M., W.D. Bauer, D.M. Bird, J. Cullimore, B. Tyler, and J.I. Yoder. 2003. Molecular signal and receptors: controlling rhizosphere interactions between plants and other organisms. Ecology 84:858-868. doi:10.1890/0012-9658(2003)084.

Islam, K.R., and R.R. Weil. 1998. Microwave irradiation of soil for routine measurement of microbial biomass carbon. Biology and Fertility of Soils 27:408-416. doi:10.1007/s003740050451.

Liang, Y.C., W. Sun, Y.G. Zhu, and P. Christie. 2007. Mechanisms of silicon-mediated alleviation of abiotic stresses in higher plants: A review. Environmental Pollution 147:422-428. doi:10.1016/j. envpol.2006.06.008.

Ma, J.F., Y. Miyake, and E. Takahashi. 2001. Silicon as a beneficial element for crop plants. Studies in Plant Science 8:17-39. doi:10.1016/S0928-3420(01)80006-9.
Moreira, F.S.M., and J.O. Siqueira. 2006. Rhizosphere. p. 407-447. In Moreira F.S.M., and J.O. Siqueira (eds.) Soil microbiology and biochemistry. Universidade Federal de Lavras UFLA, Lavras, Minas Gerais, Brazil.

Neumann, D., and U. Nieden. 2001. Silicon and heavy metal tolerance of higher plants. Phytochemistry 56:685-692. doi:10.1016/S00319422(00)00472-6.

Rangel-Castro, J.I., K. Killham, N. Ostle, G.W. Nicol, I.C. Anderson, C.M. Scrimgeour, et al. 2005. Stable isotope probing analysis of the influence of liming on root exudate utilization by soil microorganisms. Environmental Microbiology 7:828-838 doi:10.1111/j.1462-2920.2005.00756.x.

Reinhart, K.O., and R.M. Callaway. 2006. Soil biota and invasive plants. New Phytologist 170:445-457. doi:10.1111/j.14698137.2006.01715.x.

Sakamoto, K., and Y. Obo. 1994. Effects of fungal to bacterial ratio on the relationship between $\mathrm{CO}_{2}$ evolution and total soil microbial biomass. Biology and Fertility of Soils 17:39-44. doi:10.1007/ BF00418670.

Sandmann, E.R., and M.A. Loos. 1984. Enumeration of 2,4-D-degrading microorganisms in soils and crop plant rhizospheres using indicator media: High populations associated with sugarcane (Saccharum officinarum). Chemosphere 13:10731084. doi:10.1016/0045-6535(84)90066-3.

Santos, J.B., and J.P. Cury. 2011. Black jack: a special weed in tropical soils. Planta Daninha 29:1159-1171. doi:10.1590/S010083582011000500024.

Santos, E.A., L.R. Ferreira, M.D. Costa, J.B. Santos, M.C.S. Silva, and I. Aspiazu. 2012. The effects of soil fumigation on the growth and mineral nutrition of weeds and crops. Acta Scientiarum Agronomy 34:207-212. doi:10.4025/actasciagron.v34i2.12971.

Seebold, K.W., L.E. Datnoff, F.J. Correa-Victoria, T.A. Kucharek, and G.H. Snyder. 2004. Effects of silicon and fungicides on the control of leaf and neck blast in upland rice. Plant Disease 88:253258. doi:10.1094/PDIS.2004.88.3.253.

Singh, K.B., P. Millard, A.S. Whiteley, and J.C. Murrel. 2004 Unravelling rhizosphere-microbial interactions: opportunities and limitations. Trends Microbiology 12:386-393. doi:10.1016/j. tim.2004.06.008.

Tótola, M.R., and G.M. Chaer. 2002. Microorganisms and microbiological processes as indicators of soil quality. p. 195-276. In Alvarez, V.V.H., C.E.G.R. Schaefer, N.F. Barros, J.W.V. Mello, and L.M. Costa (eds.) Topics in soil science. Vol. 2. Brazilian Society of Soil Science, Viçosa, Minas Gerais, Brazil.

Vance, E.D., P.C. Brookes, and D.S. Jenkinson. 1987. An extraction method for measuring soil microbial biomass C. Soil Biology and Biochemistry 19:703-707. doi:10.1016/0038-0717(87)90052-6. 